\title{
Coğrafya Nedir?
}

Makale / Article

\section{Münür Bilgili \& Ali Osman Kocalar*}

\section{Öz}

Bu çalışmada coğrafi disiplinin en temel sorusu olan "coğrafya nedir" sorusu üzerine odaklanılmıștır. Bu tür bir soruyu elbette her disiplin kendi içerisinde sormakta ve sorgulamaktadır. Zira disiplinlerin zaman zaman nereye doğru evrildikleri ve bilim yapma şekilleri üzerine düşünmeleri sıkça rastlanılan bir durumdur. Böylece disiplinler kendi pratiklerine refleksif bir şekilde yaklaşırken aynı zamanda disiplinlerinin çizdiği yol üzerine de çıkarımlar yapmaktadırlar. Bu anlayıştan yola çıkarak çalışmamızda "coğrafya nedir" sorusuyla; coğrafyada yaşanan değişimleri, dönüşümleri, anlayışları ve coğrafyanın diğer disiplinlerle olan ilişskilerini bu soru üzerinden okumaya çalıştık. Çalışma boyunca disiplinlerin bilim yapma pratiklerinde tam bağımsız olmadıkları fikrini benimsediğimiz için, geniş bir şekilde sosyal bilimler felsefesinden, farklı yaklaşımlardan ve diğer disiplinlerden yararlanma yoluna gidilmiş̧tir. Coğrafya nedir sorusuna yanıtlar ararken bilimsel alanlarda keskin sınırların ve sınıflandırmaların olmadığına; ilişkiselliğin merkezi konumuna; disiplinlerarası yaklaşımların önemine daha fazla vurgu yapmaya çalıştık. Çalışmada; coğrafya tanımında meydan gelen değişiklikler, Beck'in metodolojik milliyetçilik kavramı, disiplinler arası yaklaşımların gerekliliği, Coğrafyada tarih yazımı konularına daha ayrıntılı yer verilmiştir. Özellikle disipliner sınırların neden katı olamayacağı üzerine eleştirel bir yaklaşım getirilmiştir.

Anahtar Kelimeler: Coğrafya, Mekân, Disiplinlerarasılık, Metodolojik Milliyetçilik, Coğrafya Felsefesi.

\section{What is Geography?}

\section{Abstract}

In this study, we focused on the question of- what is geography, which is the most basic question of the geographical discipline. Admittedly, every discipline asks and ponders on this kind of question. Therefore, it is very common for disciplines to frequently think about the direction they have taken and the ways of doing science. Thus, as disciplines approach their own practices in a reflexive manner, they also make inferences on the path of their discipline that takes. Based on this understanding, we tried to interpret the changes, transformations, understandings and their relations with other disciplines through the question of what is geography. While doing this, we tried to make use of the philosophy of social sciences, different approaches and other disciplines; in that we believe that disciplines are not totally independent when it comes to practicing science. By trying to find answers to the question of what is geography, more emphasis put especially on not constructing the sharp boundaries and classifications; the central position of relationality; the importance of the interdisciplinary approaches in scientific endeavours. In this study, definitional changes in geography, Beck's concept of methodological nationalism, the need for interdisciplinary approaches, and geographical historiography are covered in more detail. In particular, a critical approach has been adopted as to why disciplinary boundaries cannot be strict.

Keywords: Geography, Space, Interdisciplinarity, Methodological Nationalism, Philosophy of geography.

*Doç. Dr. | Marmara Üniversitesi, Atatürk Eğitim Fakültesi | munur.bilgili@marmara.edu.tr ORCID: 0000-0002-6841-4926 | DOI: 10.36484/liberal.771132

**Doç. Dr. | Marmara Üniversitesi, Atatürk Eğitim Fakültesi | ali.kocalar@marmara.edu.tr **ORCID: 0000-0002-7827-9043 | DOI: 10.36484/liberal.771132

Liberal Düşünce Dergisi, Yıl: 25, Sayı: 99, Yaz 2020, ss.145-162. Gönderim Tarihi: 18 Temmuz 2020 | Kabul Tarihi: 27 Eylül 2020 


\section{Giriş}

Konuya giriş yaparken bu çalışmada benimsenen akademik dil üzerinden bir noktaya açıklık getirmek istiyoruz. Yabancı bilimsel yayınlarda etken fiil, birincil tekil ve birincil çoğul şahıs eklerinin kullanımı yaygın bir şekilde görülmektedir. Fairchlough (2013), araştırmacıların kendi duruşlarını netleştirmeleri açısından bu tür dil kalıplarının kullanılmasını doğal karşılamaktadır. Bondi (2014), farklı sosyal disiplinleri kapsayan çalışmasında, akademik yazımdaki değişimlere dikkat çekerek son yıllarda şahıs ekleri kullanımının giderek arttığını ampirik örneklerle göstermektedir. Türkiye'de ise bilimsel yazımda çoğunlukla edilgen fiil kullanılması ve şahıs eklerinden mümkün olduğunca kaçınılması önerilmekte ve bu yaklaşımın daha bilimsel olduğu söylenmektedir. Akademik yazımda salt edilgen kullanımın benimsenmesiyle nasıl "daha bilimsel” olunabildiğinin gerekçelendirilmesi gerektiğini düşünüyoruz. Oysa herhangi bir çalışmada bizim belirttiğimiz düşünceler herkes tarafından kabul edilmeyeceği veya başkaları tarafından kabul edilen düşüncelerin bizim açımızdan kabul görmeyeceği durumlar çok yaygındır. Bu tür fikir ayrılıkları bilimin olmazsa olmazlarındandır. Bu yüzden zaman zaman şahıs ekleri içeren "düşünceme göre, düşüncemize göre” şeklindeki ifadelere ihtiyaç duyarız. Bir diğer nokta ise edilgen fiillerin kullanıldığı "bazı” durumlar oldukça sorunludur. Özellikle tartışmalı noktalarda "düşünülmektedir, paylaşılmaktadır” gibi ifadeler sanki çalışmada tartışılan fikirleri herkes paylaşıyor ve onaylıyor gibi bir algı oluşturmaktadır. Gerçekte, okurlar ilgili fikirlerin önemli bir kısmını paylaşmıyor olabilir. Doğal olarak bu tür noktalarda fikir ayrılığını vurgulamak için şahıs ekleri devreye girer. Bu nedenlerle, bilimsel çalışmalarda hem etken ve edilgen çatılar hem de şahıs eklerinin kullanımı "bizim" düşüncemize göre sorun olmamalıdır. Hatta, etken ve edilgen ifadeler nüans getirmeye yardımcı olur. Coğrafya literatürü bu tür kullanımlarla doludur. Edilgen kullanım elbette bilimsel yazımın önemli özelliklerindendir; ancak diğer dil kullanımlarına da alan açılmalıdır. Dolayısıyla, çalışma boyunca etken-edilgen fiiller ve şahıs eklerinin kullanımı üzerine aşırı titizlik göstermekten ziyade bağlamına göre uygun bulduğumuz dil yapılarını kullanmayı tercih ettik.

Öncelikle oldukça klişe görünen coğrafya nedir şeklindeki bir soruyu neden çalışmamızın başlığı olarak seçtiğimizi açıklamak istiyoruz. Elbette, bu temel soru disiplinin tarihinde çokça soruldu ve sorulmaya devam edilecektir. Ancak; aynı sorunun sorulması verilen yanıtın da aynı olacağı anlamına gelmemektedir. Diğer bir deyişle, coğrafya nedir sorusu farklı zaman dilimlerinde farklı bağlamlarda farklı mekânlarda farklı anlamlara gelmektedir 
(Livingstone, 1992). Dolayısıyla, farklı yanıtları da beraberinde getirmektedir. Hatta, coğrafyanın alt dalları nelerdir; coğrafya daha çok hangi paradigma ve yaklaşımlardan etkilenmiştir şeklindeki soruların yanıtları da aynı değildir. Disiplin değişime uğradığı için doğal olarak ilgili sorulara verilen yanıtlar ve yapılan yorumlar da değişmektedir. Coğrafi disiplinin nereye doğru yöneldiği ve gelişiminin ortaya konması açısından coğrafya nedir sorusunun hayati bir öneme sahip olduğunu düşünüyoruz. Bu nedenle çok klasik bir soruya farklı yanıtlar aramaya çalışacağız.

Bu çalışmada dönemsel ve kronoloji temelli coğrafya tanımları üzerinde durulmayacaktır. Zira bu tür tanımlar literatürde geniş bir şekilde yer aldığından aynı şeyleri tekrarlama yoluna gidilmeyecektir. Sadece yeri geldiğinde karşılaştırma, yorumlama ve çıkarım yapmak amacıyla daha klasik görülen anlayıştan örnekler vereceğiz. Çalışma boyunca güncel literatürden yararlanarak coğrafi düşüncede ne tür değişimlerin yaşandığı ortaya konulmaya çalışılacaktır. Çalışmanın sonunda ise benimsediğimiz coğrafya tanımımızı yapacağız. Okuyucuların, bu çalışmada ortaya koyacağımız bütün fikir ve düşünceleri onaylamasını; bizlerle aynı düşünceleri benimsemelerini beklemiyoruz. Yaptığımız tanım ve değerlendirmelerin mutlak doğrular olduğu şeklinde bir iddiamız da yoktur. Diğer yandan, çalışmada coğrafyanın ne olduğu ve ne anlama geldiği konularında tutarlı yaklaşımlar sunmaya çalışacağız. Coğrafyanın ne olduğu kadar ne olmadığı üzerinde de durulacaktır. Ayrıca, çalışma boyunca okuyucularla diyaloğa girerek coğrafyanın ontolojisi, epistemolojisi ve metodolojisi üzerine verimli tartışmaların ortaya çıkmasına katkı sağlamayı amaçlıyoruz.

Çalışma boyunca coğrafyanın bilim yapma pratiği bağlamında hiçbir zaman bağımsız olmadığı tezini savunduktan sonra; disiplinin geçirdiği tanım değişimleri ele alınacaktır. Disiplinler arası yaklaşımların bir zorunluluk olduğu düşüncesinden yola çıkarak Türkiye'deki bazı coğrafya yapma pratiklerini metodolojik milliyetçilik kavramı üzerinden değerlendireceğiz. Coğrafya ne değildir konusu ele alındıktan sonra, coğrafyanın historiyografisi üzerine odaklanılacaktır. Sonuç kısmında ise genel bir değerlendirme yapılacaktır.

\section{Coğrafyanın Bağımsızlığı ve Tanım Değişimleri}

Coğrafya, tüm dünyada farklı zaman dilimlerinde kurumsallaşarak otonom bir yapıya kavuşmuştur. Coğrafya'nın 19. yüzyılın sonlarından itibaren bölümleri, araştırma enstitüleri, dergileri, öğrencileri ve akademisyenleri ile bağımsız disipliner bir kimliğe kavuştuğu belirtilmektedir (Johnston ve Sidaway, 2015). Her ne kadar bu kurumsal yapı otonom bir özellik gösterse de 
coğrafyanın bilim yapma pratiği hiçbir zaman otonom ve bağımsız olmamıştır. Aslında hiçbir disiplin; işleyiş, metodoloji, paradigma ve yaklaşım konularında bağımsız değildir. Çoğu zaman disiplinlerin bağımsız birimler haline gelmeleri onların bilim yapma şekillerinin de bağımsız olduğu algısını beraberinde getirmektedir. Bu nedenle, bir disiplinin kurumsal bağımsızlığı ile onun bilim yapma pratiğindeki bağımsızlığının eşdeğer olduğu şeklinde bir sonuca kolaylıkla varılmamalıdır.

Coğrafya diğer disiplinler gibi farklı yaklaşımlar, fikirler ve düşüncelerle şekillenmektedir. Bu şekillenmeyle, bilim dünyasında sıkça dillendirilen interdisiplinerlik, transdisiplinerlik (Frodeman, 2017; Klein, 2017) ve postdisiplinerlik (Jessop ve Sum, 2003) kavramlarından bahsetmiyoruz. Daha fazlasının var olduğunu ve disiplinlerin birbirine parazitik olduğunu söylemek istiyoruz. Agnew'in (2011) kavramını kullanacak olursak; mekân, objeler arasındaki ilişkilere ve yerler üzerinde meydana gelen faaliyetlere parazitiktir. Onlarsız bir şey ifade etmez. Dolayısıyla, Coğrafya da diğer disiplinlere parazitiktir. Coğrafya, her türlü faaliyeti mekân üzerinden okuma halidir, mekânsal bir perspektiftir (Bathelt ve Glückler, 2011). Bu tanımdan yola çıkarak şöyle bir soru sorabiliriz: Mekânsal perspektiften her türlü faaliyeti yorumlayan coğrafya, bu faaliyetler olmadan ne anlama gelirdi? Büyük olasılıkla hiçbir şey. Coğrafya; üzerinde yaşanan politik, ekonomik, kültürel, sosyal, demografik ve fiziksel değişmeler, etkileşimler, dönüşümler ve çatışmaların mekânsal bir perspektiften okunması anlamına geliyorsa; o halde Coğrafya bu faaliyetlere bağımlıdır. Onlar olmadan Coğrafyanın da bir anlamı yoktur. Bu durumda Coğrafya biliminden de bahsedilemezdi. Çünkü bireysel ve kolektif insan faaliyetleri olmadan bugün Coğrafyada üzerinde konuştuğumuz mekânsal örüntüler, mekânsal teoriler ve mekânsal özelliklerin hiçbiri ortaya çıkamazdı. Bundan dolayı, disiplinler arası çalışmalar ve yakınlaşmalar bir seçenek olmaktan ziyade açık bir zorunluluk olarak önümüzde durmaktadır. Daha önceki paragrafta belirtildiği gibi bilim dallarının pratiğinde tam bağımsızlık aramak ve böyle bir bağımsızlığın var olduğu geçmişte düşünülse bile günümüz düşüncesinde imkânsızdır.

Coğrafya yerin tasviridir. Coğrafya insan ve çevre arasındaki karşılıklı etkileşimleri inceler. Coğrafya sürekli dönüşen mekânı anlama çabasıdır. Coğrafya tüm insan faaliyetlerini mekânsal perspektiften anlamaya ve yorumlamaya çalışır... (Gregory, 2009; Livingstone, 2009). Klasik ya da güncel bu tanımlamalar coğrafyanın onlarca tanımından sadece birkaçını oluşturmaktadır. Tüm tanımların öznesi Coğrafya iken; yüklem ve nesneleri farklıdır. Doğal olarak buradan şu çıkarım akla gelebilir. Değişmez, katı ve öz bir Coğrafya vardır. Çünkü özne olan Coğrafya hep orada durmaktadır. Sadece ona yüklenen anlamlar 
değişmiştir. Robert Mesle (2008), Süreç Felsefesi adlı kitabında farklı bağlamdan benzer durumu, "dilsel bir yanılma ve bu yanılmanın yol açtığı yanlış bir düşünme şekli” olarak açıklamaktadır. Yukarıda verilen alıntılardan Coğrafya tanımının önemli oranda değiştiği görülmektedir. Sadece aynı “Coğrafya” öznesi sürekli orada bulunduğu için dilsel bir sabitlikten değişmez bir gerçeklik çıkarıyoruz veya öyle olduğunu düşünüyoruz. Coğrafya adının bizzat değişmemesi onun değişmediği anlamına gelmiyor. Öznenin aynı olması değişmeye engel olmadığı gibi bu durumun bizi özcü bir coğrafya anlayışa götürmemesi gerekir.

Coğrafya tanımlarında sürekli olarak insan-çevre/insan-mekân şeklinde ikili bir yapı üzerinden açıklamalara gidilmektedir. Bu yaklaşım hayli problemli görülmektedir. Zira bu şekilde yaklaştığımızda mekânı, insan dışında kendi kendine var olan ve kendi yasaları bulunan otonom bir yapı; bir varlık (entite) olarak görme eğilimi ortaya çıkmaktadır (Sayer, 2000). Tamamen insan ilişkilerinin dışında yer aldığı düşünülen mekân ve coğrafyadan bilimsel sonuçlar çıkarmamız imkânsızdır. Çünkü mekân onlarla vardır. "Coğrafya, insan ve mekân arasındaki karşılıklı etkileşimleri inceler” şeklindeki tanımda yer alan mekân, insansız ve onun faaliyetlerinden yoksun mekân anlamına gelmemektedir. İnsan etkinlikleri ve deneyimlerden yoksun bir mekân/coğrafya (literatürde bazen bağlamına göre eşanlamlı olarak da kullanılmaktadır) tahayyülü mevcut coğrafya düşüncesiyle bağdaşmamaktadır. Çünkü “Coğrafya insan ve mekân arasındaki karşılıklı etkileşimleri inceler” ifadesindeki "insan" ve "mekân" hiçbir zaman birbirinden ayrı değildi. Mekân ve insanı ayrı düşünme şekli Coğrafyanın daha pozitivist olduğu Bölgesel Coğrafya ve Nicel Devrim dönemlerinin göze çarpan özelliklerinden biriydi (Bathelt ve Glückler, 2011).

Coğrafyanın önemine vurgu yapılmak istendiğinde en sık kullanılan görüşlerden biri: “Bütün faaliyetler mekân üzerinde yer almaktadır ve tümünün coğrafi bir boyutu vardır. Bu nedenle coğrafya vazgeçilmezdir” şeklinde ileri sürülmektedir. Elbette tüm deneyimlerimiz, yaşantılarımız ve faaliyetlerimizin coğrafi bir boyutu vardır. Sonuçta belirli bir coğrafya üzerinde yaşıyoruz; ancak bu düşünce temelinde yatan coğrafya, günümüz coğrafya anlayışı ile tam olarak uyuşmamakta ve önemli oranda eksik bulunmaktadır (Crang, 1997; Sayer, 1992:2000; Özkaya, 2020). Çünkü bu tür düşüncedeki coğrafya ağırlıklı olarak yeryüzü özelliklerine göndermelerle yüklüdür. Böyle bir etki tabii ki vardır; fakat insan fazlasıyla arka plana atılmıştır. Zira insanın coğrafyayı dönüştürerek yaşanır veya yaşanmaz kılmasındaki rolünü nereye koyacağız? En kuvvetli argümanımız sadece "her şeyin coğrafi bir boyutu vardır" mı olmalı? En önemli varoluş gerekçemizi "tüm insan faaliyetlerinin devamlılığı için 
coğrafyaya ihtiyaç vardır” üzerine mi inşa edeceğiz? Bu tür klişe argümanların yerine, olguların yaşanmasında mekân ve mekânsal pratiklerin olumlu/ olumsuz etkilerinin neler olduğunun ortaya konması daha coğrafya olacaktır.

\section{Sınırlar, Disiplinlerarasılık ve Metodolojik Milliyetçilik}

Gündelik hayatta deneyimlerimizi daha bütüncül bir şekilde hissederiz. Her tecrübe ve deneyimi iç içe, birbirleriyle az veya çok ilişkili bir şekilde yaşıyor veya öyle anlamlandırıyoruz. Bilim ise, kaynağını aldığı yaşamın aksine aşırı branşlaşmayla fazlasıyla parçalı durmaktadır. Yaşamdan kaynağını aldığı için, bilimin de böyle olması gerektiğini savunmuyoruz; ancak bu derece parçalılık ne kadar sürdürülebilir? Bu parçalılıktan, gerçekliği daha bütüncül yakalayabilir miyiz? Kapsamlı branşlaşmanın yan etkileri son yıllarda daha da akut bir şekilde hissedilmeye başlandı. Zira farklı disiplinler arasında parçalılığın yanı sıra disiplin içi parçalılık da giderek açılmaya başladı. Bu eğilimlere karşıt olarak son dönemlerde özellikle beşeri ve sosyal bilimlerde disiplinler arası çalışmalar giderek daha görünür hale gelmeye başlamıştır (Moran, 2002; Klein ve Frodeman, 2017). Bu girişimlerin temel nedeni, giderek ortadan kaybolan bütüncül perspektife olan ihtiyacın yoğun olarak hissedilmesiyle açılkanabilir.

Konuyu, bahsettiğimiz yaşam-bilim ilişkisinden bir örnekle açmaya çalışalım: “Alışveriş yapma” pratiğinden yola çıkarsak bu pratiğin sosyolojik, psikolojik, ekonomik, coğrafi, kültürel, politik ve birçok farklı boyutu vardır. Disiplinler aynı olguları kendi spesifik perspektiflerinden ele alırlar. Bu pratiğin sosyolojik bir yönü vardır. Zira alışveriş yapma pratikleri toplumsal değişim hakkında bilgiler sunar ve sınıfsal farklılıklar üzerine çıkarımlar yapılmasına imkân verir. Bu pratik psikolojiktir çünkü bireylerin alışveriş yapma sıklığı ile psikolojik duygu durumları arasında önemli ilintiler bulunmaktadır. Bu pratik, ekonomik bir pratiktir ve ekonomik trendler hakkında veriler elde edilebilir. Bu pratik aynı zamanda mekânsal bir pratiktir; zira alışveriş yapma pratikleri farklı mekânsal üretimleri ve deneyimleri ortaya çıkarır. Bu pratik kültürel bir pratiktir çünkü tüketime dayalı kimlik oluşumu günümüzde önemli bir olgu olarak kabul edilmektedir. Ayrıca, alışveriş yaparken ürün fiyatlarından, arz-talep durumundan, hangi ürün türünün daha çok tüketildiğinden yola çıkarak bir ülkenin siyasi durumu hakkında bile bazı çıkarımlar yapılabilir. Bir örnekten yola çıktığımızda bile sosyoloji, psikoloji, coğrafya, etnografya, kültürel çalışmalar, antropoloji, siyaset bilimi ve daha birçok bilim dalının dahlini görebiliriz. Yani aynı deneyime farklı açılardan hepsi müdahildir. Farklı disiplinlerin farklı bakış açılarına odaklanarak daha derin 
analizler sağlamalarına karşın aşırı derecede disiplin sınırlarından bakmak belirli bir anlam kaybını da beraberinde getirerek kırılmalara yol açmaktadır. Eğer her disiplin bir perspektif veya bir pencere ise; bu disipliner pencereleri her mevsim açık tutmamız gerekmektedir. Zira Coğrafya da dâhil olmak üzere hiçbir disiplin kendi kendine yetemez.

Coğrafyacılar arasında bazen çalışmaların coğrafya olup/olmadığına dair söylemler bulunmaktadır. Hatta dergi editörlüğü yapan akademisyenler, dergilere gönderilen belirli makalelerin "bu çalışma coğrafya çalışması değil" gerekçesiyle hakemler tarafından sıklıkla reddedildiğini belirtmektedirler. Okuduğunuz bu çalışmanın yazarlarına göre; böyle bir gerekçe bir makaleyi reddetmek için belki de en son nedenlerden biri olabilir. Öncelikle bir çalışmanın amacı, metodu, kullandığı dil, sunduğu katkı, bulguları, literatürü ve metodolojisi üzerine birçok yönden eleştiriler getirebilir. Bu son derece doğaldır ve bilimsel süreç bilindiği gibi bu şekilde işlemektedir. Peki, disiplinlerin bu kadar iç içe olduğu; sınırlarının giderek flu hale geldiği; disiplinlerin bir perspektif olarak kabul edildiği bir durumda; herhangi bir coğrafya makalesinin coğrafya olmadığına nasıl karar verilmektedir? Disiplindeki çalışmalar nasıl "bu coğrafya", "bu coğrafya değil" denilerek adeta papatya falını andıran bir şekilde kolayca sınıflandırılabilmektedir? Bir çalışmanın coğrafya çalışması olarak kabul edilip edilmemesi üzerine literatürde keskin kriterler mi bulunmaktadır? Eğer varsa bu kriterler nelerdir? Bir noktayı tekrar etmekte fayda var. Herhangi bir çalışma mekânsal perspektifi zayıf, yetersiz, eksik veya yanlış vermiş olabilir ve bu açılardan elbette çalışmalar rahatlıkla reddedilebilir; fakat bu noktada sormak istediğimiz soru çok açık: ilgili çalışmaların coğrafya olmadığına nasıl kolaylıkla karar verilebilmektedir?

Yukarıda ifade edilen gelişmelere kısa da olsa Türkiye ekseninden bakmaya çalışalım. Son yıllarda coğrafya ve diğer disiplinler arasındaki etkileşimlerin yararlı sonuçlarını Türkiye'de yapılan birçok çalışmada görebiliriz. Mekânsal odaklı bu çalışmalarda birçok farklı bakış ve yaklaşımın Coğrafyaya taşındığı görülmektedir. Ele alınan konular ve içerikleri hayli farklıdır (Özgür, 2019; Deniz, 2020; Öksüz ve Deniz, 2019; Yakar ve Südaş, 2019; Tüysüz ve Gülmez, 2019; Miroğlu, 2018: Arı, 2017; Uysal, 2015). Aynı zamanda mekânsal bakış açısı da diğer disiplinlerin katkısıyla giderek zenginleşmektedir (Kurtar, 2020; Tuncer, 2018; Anlı, 2016:2017). Bu olumlu gelişmelere karşın Ulrich Beck'in (2009) Sosyoloji bağlamında kullandığı "metodolojik milliyetçilik" kavramını Türkiye'deki bazı coğrafya yapma pratiklerine adapte edebiliriz. Beck, çalışmasında küreselleşme ile birlikte tüm dünyada materyal ve sosyal gerçekliklerin önemli oranda değiştiğini; buna karşın yaşanan değiş̧ikliklerin bilimsel metodolojiye tam olarak yansımadığını belirtmektedir. Ona 
göre, yalnızca ulus-devlet penceresinden bakarak doyurucu açıklamalara ulaşamayız. Zira küreselleşme her noktaya nüfuz ettiği için, analiz ünitesini ulus-devlet ile sınırlamak değişen gerçeklikleri yeteri derecede yansıtamaz. Beck'in bu analizinden yola çıkarak Türkiye'de, betimleyici özelliği yüksek; teorik altyapıları zayıf; bölgeselciliği yoğun; klasik pozitivizm temelli ve yeryüzüne yoğunlaşmaktan insanın fazlaca geri plana atıldığı Coğrafya anlayışını "lokal metodolojik milliyetçilik" olarak adlandırabiliriz. Beck, çözüm olarak küresel bakışa daha fazla alan açan ve katı ulus-devlet sınırlarını aşmayı amaçlayan "metodolojik kozmopolitanizm” kavramını önermektedir. Aynı doğrultuda, Türkiye'deki coğrafya anlayışında da disiplin sınırlarından ziyade çalışmaların katkı ve verimliliğine daha fazla odaklanan; farklı disiplinlere daha açık metodolojik kozmopolitanizme ihtiyacımız vardır. Nitekim Arı (2019), Özgür (2018), Bekaroğlu ve Yavan (2018) Türkiye'de bu yaklaşımın işaretlerinin olduğunu; farklı şekillerde coğrafya yapma biçimlerinin daha görünür olmaya başladığını; ancak bunun yeterli olmadığını vurgulamaktadırlar. Adına yenilikçi, gelenekçi, modern, klasik, içe kapalı, dışa açık ne şekilde ifade edersek edelim bütün yaklaşımlar farklı yoğunlukta fakat aynı zaman diliminde yaşanmaktadır; fakat ihtiyacımız olan yeni düşüncelere açık bir Coğrafya olduğu kuşkusuzdur.

Coğrafyada içerikten ziyade sınırlara odaklandıkça daha fazla içe kapanıyoruz. Bu sınırlar ister istemez zihin haritamızın bir parçasına kalıcı olarak yerleşmektedir ve sökülmesi de çok kolay değildir. Eski Roma mitolojisinde Tanrı Janus'un iki yüzü vardır ve bu yüzlerden biri geçmişe diğeri ise geleceğe bakar. Başlangıçlar ve bitişler tanrısıdır; geçişleri, eşikleri ve geçitleri iki yüzü ile mükemmel bir şekilde kontrol edebilir (Nardo, 2002). Günümüzde, sosyal bilimlerin ve dolayısıyla coğrafyanın geldiği noktayı dikkate alırsak; bizlere coğrafyanın nerede başlayıp nerede bittiğini söyleyecek; geçişleri ve geçitleri dikkatlice kontrol edecek; disiplinin sınırlarını itinayla çizecek bir Janus'a ihtiyacımız yoktur. Israrla Coğrafyada Janus'u aramak ve disipliner sınır polislikleri oluşturmak sadece görüş açımızı daraltıp düşünce dünyamızın kısırlaşmasına yol açacaktır. Coğrafyada ve daha geniş bağlamıyla sosyal bilimlerde günümüzde daha gerekli görülen bilim dalları arasındaki etkileşim, sinerji, fikir ve düşünce akışlarıdır. Bu nedenle Coğrafyada ihtiyacımız olan ne Panoptes'in yüz gözü ne de Janus'un iki yüzüdür.

\section{Coğrafya Ne Değildir?}

Bu başlık altında coğrafyanın daha çok "ne olmadığı” üzerine yoğunlaşmak istiyoruz. Bireyler, toplumlar, disiplinler, devletler, siyasi görüşler hangisini 
ele alırsak alalım kendilerini tanımlarken ne olduklarının yanı sıra ne olmadıklarını da belirtme ihtiyacı duyarlar. Ne olmadıkları en az ne oldukları kadar önemlidir. Özellikle, bireyler ve bilimsel disiplinler ne olmadıklarını belirtme konusunda oldukça cömerttirler ve bu durumu gündelik yaşamımızda sıklıkla tecrübe ederiz. İronik olan ise, ister bireyler isterse disiplinler olsun; kabul etmedikleri özellikleri zıt yönden kendilerini tanımlamanın birer aracı haline dönüştürmeleridir. Bu nedenle, coğrafyanın ne olduğu kadar ne olmadığını da belirtmemiz gerekir. Günümüz coğrafya anlayışına ters düşen bazı argüman ve yaklaşımların coğrafyayı destekler mahiyette görünmelerine karşın ortaya çıkan tablonun böyle olmadığına işaret etmektir.

İbn Haldun'un “coğrafya kaderdir” sözünün günümüzde fazlaca kabul görmesine karşın bu yaklaşım günümüz coğrafya anlayışı ile uyuşmamaktadır (Bilgili, 2020). Tüm disiplinlerdeki kaderci anlayış determinizme çıkmaktadır. Buna; tarih, toplum, kültür, ekonomi, siyaset ve biyoloji de dâhildir. Bu tür yaklaşımlardaki temel sorun "etki" etmenin "belirleme” seviyesine taşınmasından ileri gelmektedir. Ancak, etki ve belirleme arasında uçurum vardır. Belirleyicilik yüklü bir anlama sahip olan kader, çıkmaz bir sokaktır zira her şeyi insan iradesinin dışına çıkarır. Doğal olarak bağlamına göre coğrafyanın, tarihin, toplumun, ekonominin, kültürün veya biyolojinin kaderine dönüşürüz. Bunların hiçbirinin kader olmadığı Acemoğlu ve Robinson (2012) tarafından farklı kıtalardan verilen ampirik örneklerle gösterilmektedir. Çalışmalarında ABD, Meksika, İngiltere, Güney Kore, Botsvana ve daha birçok ülkeden örnek-olay vererek ne coğrafyanın ne tarihin ne toplumun ne de kültürün kader olamayacağ1; ulusların gelişmelerindeki en önemli unsurun insan ve onun potansiyeli olduğu sonucuna varmışlardır. Bu yaklaşım, coğrafya da dâhil bütün sosyal disiplinlerin üzerinde uzlaşı sağladıkları bir yaklaşımdır. Bundan dolayı "Coğrafya da kader değildir."

Yves Lacoste’un, (1976) “Coğrafya savaşmak içindir” ifadesi gerçeği yansıtmamaktadır ve en azından coğrafyanın böyle bir amacı yoktur. Kitabın yazıldığı dönemi dikkate alsak dahi böyle bir tanımlamayı coğrafyaya eklemleyemeyiz. Coğrafya; savaşmanın, ezmenin, hegemonya kurmanın, kolonize etmenin ve emperyalizme destek olmanın aracı olarak görülemez. Lacoste'un tezinin aksine Coğrafya salt araçsallığa indirgenemez. Amaç ve pratik ilişkilidir fakat aynı şeyler değildir. Coğrafyanın geçmişinde elbette bunların hepsi yaşandı ve coğrafya ezmenin aracı olarak sıklıkla kullanıldı. Coğrafyanın bu şekilde kullanılmış olması ilgili özellikleri coğrafyanın tanım ve amaçlarına sokulması anlamına gelmemelidir. Nitekim, günümüzde bu tür yaklaşımlar yoğun bir şekilde eleştirilmekte ve coğrafyanın böyle olamayacağına dair 
güçlü bir literatür bulunmaktadır (Tuathail, 1996; Tuathail ve Dalby, 1998; Agnew, 2002:2003; Sharp, 2008; Dodds, Kuus ve Sharp, 2013).

Akademide olmasa bile medyada sıklıkla dillendirilen "Coğrafya bilimlerin kraliçesidir” ifadesi de sorunludur. Kuşkusuz, bu ve benzeri sloganlar coğrafyayı yüceltmek adına iyi niyetle kullanılmaktadır; ancak, bu tür sloganlar da ciddi sakıncalar içermektedir. Birincisi, coğrafyayı gereksiz bir şekilde romantize etmekte ve disiplinin gerçekte ne anlama geldiğini gölgelemektedir. İkincisi, bilim dalları için bu tür ifade ve benzetmelerin kullanılması belirli bir hiyerarşiyi akla getirmektedir. Coğrafya, bilimlerin kraliçesi ise, bilim dalları arasında bir ast-üst ilişkisi vardır ve kraliçe olan Coğrafyanın altında ona tabi olan diğer disiplinler olmalıdır. Elbette, gerçekte böyle bir durum yoktur; fakat bu tür sloganlar hiyerarşiyi çağrıştırmaktadır. Bilim dalları arasındaki bu tür hiyerarşik yaklaşımların hiçbir faydası bulunmamaktadır. Coğrafya veya diğer disiplinlerden yapılan her türlü bireysel ve disipliner hiyerarşizm girişimlerini gereksiz, verimsiz, bilimsel anlayıştan uzak, ego-merkezli ve enerji israfı olarak görüyoruz.

Coğrafya ayrıca yeryüzünü betimlemek ve tasvir etmek değildir. Bu noktada coğrafyada hiçbir şekilde betimleme yapılmayacağı kolaylıkla söylenemez. Zira her çalışma az veya çok betimleme içerir. En azından çalışmaların girişinde araştırmacılar kısa da olsa betimleme yapma ihtiyacı duyarlar. Ancak, çalışmalar tamamen tasvire, betimlemeye ve tanımlamaya yönelik olduğu zaman eleştiriler artmaktadır. Çünkü tasvir yapısı gereği analiz, yorumlama ve açıklamaya fazlasıyla kapalıdır ve işlevselliği belirli bir yere kadardır. Coğrafi tasvirlerden, coğrafya için olmazsa olmaz olan mekânsal teoriler, yaklaşımlar ve örüntüleri çıkaramayız. Bu nedenlerle, tasvir ve betimlemelerin Coğrafyada yeri olmasına karşın bu yerin kapladığı alan oldukça mütevazı olmalıdır. Tasvirler çalışmaların ana omurgasını oluşturacak seviyeye çekilmemesi gerekir.

Coğrafya, ayrıca devasa büyüklükteki fen ve sosyal bilimler arasında yer alan bir köprü değildir. Sadece onlara mekânsal bir perspektif sunarak anlama ve yorumlama çabalarına yardımcı olur. Çoğu coğrafyacının çalışmalarını sürdürürken acaba fen ve sosyal bilimler arasında nasıl köprü olabilirim diye bir kaygısı yoktur. Coğrafya, varlığı şüpheli bölgeler, anlamsız kategoriler ve temelsiz sınıflandırmalar oluşturmak değildir. Daha çok farklı faaliyetlerin işleyişinde mekânsallık ne derece etkili olmuştur; bu faaliyetler arasında anlamlı mekânsal örüntüler var mıdır şeklinde sorulara yanıtlar aramaktadır. Coğrafya, olgulara yaklaşırken mekânsal faktörü dışarda ve içerde tuttuğumuzda ne tür farklar ortaya çıkar/çıkabilir şeklindeki reel 
ve hipotetik sorular üzerine daha çok odaklanmaktadır. Coğrafi disiplinde genellikle kesin ve değişmez bilimsel yasalar aranmaz. Zira sosyal bilimler insan merkezli olduğu için zamanı ve mekânı aşan bilimsel yasalara varılabileceğine kuşkuyla yaklaşır (Packer, 2011).

\section{Coğrafyanın Tarih Yazımı (Historiyografisi) ve Gelenek}

Historiyografi (Historiography) tarih yazımı anlamına gelmektedir ve bütün disiplinlerin çalışma alanlarından biridir. Zira bütün bilim dalları kendi tarihlerini farklı perspektiflerden yazmaktadır. Historiyografi bir disiplinin tarihinin içeriğinden ziyade tarih yazımının nasıl oluşturulduğu üzerine odaklanır. En önemli çalışma konuları tarih yazımındaki metodolojiler, tarih-yazımı formları ve benimsenen yaklaşımlardır (Ankersmit, Domanska ve Kellner, 2009).

Coğrafyanın tanımını yaparken sıklıkla coğrafyanın tarihine dönüyoruz ve yazılan tarihten anlamlar çıkararak tanımlamalara ulaşıyoruz. Coğrafyanın tarihi ile geçmişinin aynı olduğu savı veya düşüncesinden yola çıkıyoruz. Oysa Alun Munslow'un (1997) dediği gibi “tarih” ve "geçmiş” aynı şey değildir. Tarih, yaşanan gerçekliğin ve geçmişin temsilidir. Bu nedenle tarih, geçmişin yerini alamaz. “Tarih” eşittir "Geçmiş” anlayışı Munslow’a göre yanılgıdır. Tarih; içinde doğrular, gerçekler, hakikatler kadar yalanlar, çarpıtmalar ve çıkar ilişkilerini barındırır. Geçmişin mutlak karmaşasından ahenkli bir tasarım, anlamlı bir öykü, her halkası yerli yerinde bir zincir, etkileyici bir anlatı/söylem/epistem oluşturuyoruz (Foucault, 1972 passim) ve adına tarih diyoruz. Tarihçi, bir araya getirmeden önce tarih ve geçmişin birbiriyle ilgisi yoktur, aralarında çağlar uzaklığında mesafe vardır (Jenkins, 1991). Bu nedenle tarihçi tarafından geçmiş yazılana değin ortada okurun okuyabileceği bir tarih yoktur (Munslow, 2000) ve tarih inşa edilmelidir. Yaşanan gerçekliğe ne derece bağlı kalındığından bağımsız olarak, tarihin olması için yazılması ve bu yazılanların öyküleyici (narrative) bir forma sokulması gerekir. Geçmiş, bize tarih yazımı için bir çerçeve sunmuyor; tarihçi bir çerçeve oluşturup geçmişi oradan okuyor.

İster Coğrafya ister farklı bir disiplin olsun ilgili disiplinin tarih yazımında tarihçi, belirli bir düşünce şeklini, benimsediği teorik yaklaşımları ve belirli metotları geçmişin üzerine yükler (White, 1987) ve geçmişi bu teorik gözlerle okur. Tarihçi, geçmişte yaşananları olabildiğince geçmişin penceresinden bakmaya çalışsa da zihnindeki tarih-yazımı yaklaşımları ve düşünce stilleri bugünün ürünüdür (Munslow, 2000). İkinci nokta ise, geçmişin kopyasını okumuyoruz. Yaşanan geçmişin farklı versiyonlarını farklı yazarlardan tarih olarak okuyoruz (Jenkins, 1991; Munslow, 1997). Bu noktada ifade edilmek istenilen 
tarihin tamamen yanlış olduğu; tarihi yazanların taraflı ve önyargılı olduğu değil (aslında bu tür yaklaşımlar da epeyce görülür); bahsedilen noktalardan dolayı geçmiş=tarih denkleminin imkânsız olduğudur. Coğrafi disiplinin tarihini yazarken bu perspektifin de göz önünde bulundurulması elzemdir.

Coğrafyanın tanımını ve tarihini oluştururken doğal olarak disiplinin geçmişine başvuruyoruz. Zamanında "ana akım” görülmeyen kişi ve düşünceler, günümüz fikirleriyle uyuşuyorsa ön plana çıkarıyoruz. Sıklıkla coğrafyada bu çalışmaların ne kadar önemli olduğunu vurguluyoruz. Bu durumun zıddı da yaşanmaktadır. Yani döneminin coğrafyasında ana akım olan kişi ve düşünceler günümüz anlayışıyla belirgin şekilde çelişiyorsa; onları yok saymasak bile geri plana atıyoruz. Birinci duruma örnek olarak Elisée Reclus ve Peter Kropotkin isimlerini verebiliriz. Günümüz Coğrafyası, eleştirel teorilerden önemli oranda etkilenmektedir. Bilindiği gibi bu teoriler ezilen merkezlidir ve odak noktaları ezilenlerin sorunlarıdır. Eleştirel teorilerden beslenen Coğrafya ile Reclus ve Kropotkin'in ezilmeye karşı olan duruşları fazlasıyla paralellik göstermektedir. Bu nedenle ilgili isimler daha fazla Coğrafyanın merkezine çekilmekte ve yaptıkları çalışmalar daha fazla ilgi görmektedir (Springer, 2018: Çev: Toprak; Johnston ve Sidaway, 2015; Harvey, 2012; Peet, 1998). Hatta gördükleri ilgi yaşadıkları dönemde gördükleri ilginin çok üzerindedir. İkinci duruma örnek oluşturacak figürler ise Friedrich Ratzel ve Karl Haushofer olarak görülebilir. Ratzel ve Haushofer, ezen merkezli jeopolitik yaklaşıma yakın görüldükleri için (Nayak ve Jeffrey, 2011; Johnston ve Sidaway, 2015) bu yeni çerçevede daha silik kalmışlardır. Geçmiş aynı geçmiş olmasına karşın; bu geçmişin tarihi günümüzde farklı yazılmaktadır. Zira teorik çerçevelerimiz değişmiştir. Değişen çerçeve doğal olarak disiplinin tarih yazımında da etkili olmaktadır. Bu yeni tarih yazımı doğal olarak farklı çerçeveler kullanmaktadır. Bu çerçevelere uyan isimlere doğal olarak daha geniş yer ayrılmıştır. Tarih yazımı sadece doğruyu elde etmek değil aynı zamanda doğruyu üretmeyi de içermektedir (Munslow, 1997). Nitekim günümüz coğrafyasında Reclus ve Kropotkin'e daha fazla alan açllırken, Ratzel ve Haushofer'in arka plana çekilmesinin doğru olduğu da düşünülmektedir (Peet, 1998). Çünkü coğrafyanın tarihine bakış açımız değişmiştir. Bu nedenlerle, kavramsal çerçevelerimiz ve kullandığımız teoriler sadece geçmişi tarih olarak yazmamıştır; onu şekillendirip içeriğine de etki etmiştir. Dolayısıyla, tarih yazım çerçevesi, teorik yaklaşımlar ve içerik değişiyorsa Coğrafyanın tanımı da elbette değişmiştir.

Eric Hobsbawm (1983), Geleneklerin İcadı (Inventing Traditions) adlı çalışmasında farklı bir noktaya vurgu yapmaktadır. Ona göre, gelenekler icat edilmiştir. Gelenekler belirli değer ve normları telkin ve tekrar yoluyla aşılamayı amaçlar. Bunu yaparken mümkün olduğu kadar geleneğin bir tarihi 
olduğu ve devamlılık arz ettiği düşüncesini yerleştirmeye çalışır. Yazar, icat edilen geleneklere örnek olarak bazı mimari tarzlar ve sosyal hareketlerden örnekler vermektedir.

Hobsbawm'ın bu yaklaşım tarzı Coğrafya'da tarih-yazımı üzerinde oldukça etkili olmuş ve gelenek kavramı, coğrafya historiyografisinin bir parçası haline gelmiştir. Nitekim Hobsbawm'dan etkilenen ve Coğrafya'yı gelenek olarak adlandıran David Livingstone'un (1992) ünlü eserinin adı "Coğrafi Gelenek"tir (The Geographical Tradition). Coğrafi disiplinin tümünü gelenek olarak adlandıran Livingstone'un yanı sıra coğrafi düşünce gelişimi içinde farklı gelenekler ortaya çıkmakta veya icat edilmektedir. Bu yaklaşımlara gelenek densin ya da denmesin, bu oluşumlar daha farklı fikirleri ve temsilcileriyle kendilerine daha spesifik odak oluştururlar. Örneğin, 1960'lı yılların sonunda kadın hakları, işçi hakları ve anti-koloniyalizm haklı gerekçelerle tüm dünyada daha görünür olmuştur. Bu gelişmelere doğal olarak kayıtsız kalamayan Coğrafya da kadın sorunlarını analiz odağına yerleştiren Feminist Coğrafya (Nelson ve Seager, 2005) geleneği ortaya çıkmaya başlamıştır. Aynı doğrultuda, kapitalist işleyişin olumsuz etkileri ile çalışanların sorunlarını merkezine alan Marksist ve Radikal Coğrafya (Peet, 1998), kolonyalizm ve hegemonya karşıtı Eleştirel Jeopolitik (Tuathail, 1996) gelenekleri daha görünür olmuştur. Bu ve benzeri bilim yapma stilleri farklı bakış noktalarından yaklaşım veya paradigma olarak da isimlendirilmektedir (Hubbard, Kitchin, Bartley ve Fuller, 2002). Adlarına ne dersek diyelim bu tür gelenekler/paradigmalar anlamlı inşalardır ve disiplinlere kendi tarih-yazım stillerini, tanımlarını, itirazlarını ve fikirlerini taşıyarak onları zenginleştirirler. Zira geleneklerin icad, hissedilen ihtiyaçlardan ileri gelmektedir. Nitekim günümüzde Feminist Coğrafya, Marksist ve Radikal Coğrafya ve Eleştirel Jeopolitik ve daha birçok geleneğin olmadığı bir Coğrafyanın ne kadar sığ kalacağı açıktır. Ayrıca, geleneklerin içeriklerinden bağımsız olarak; gelenek anlayışının bizzat kendisi Coğrafyadaki tarih-yazımı çerçevelerinden biri haline gelmiştir. Gelenek çerçevesinden Coğrafya az veya çok ama mutlaka daha farklı görülüp öyle yorumlanmaktadır. Hatta bahsettiğimiz gibi Livingstone bizzat gelenek anlayışını coğrafyanın tanımına yerleştirmiştir.

Gelenek anlayışı (etkisi uzun süre devam eden anlamıyla), Coğrafyanın tarih yazımında bir çerçeve oluşturup anlam oluşturmaya katı sağlamasına karşın bazı noktalara dikkat edilmelidir. Teorik altyapısı dolu olmayan, farklı olmak isteyen ancak farklılık getiremeyen ve hangi ihtiyaca karşılık geldiğini açıklayamayan gelenek veya paradigma girişimleri kısa sürede akademik peyzajdan silinmekte veya görünürlük dereceleri düşmektedir. Bazen bu tür durumlar akademik moda (academic fashion/fad) olarak adlandırılmaktadır 
(Bachmann-Medick, 2007). Yeni gelenek veya paradigma ortaya çıkarma girişimleri moda olarak görülüyorsa; bu yaklaşımın kesinlikle geçici olduğu ve zamana direnç gösteren geleneğe dönüşemeyeceğinin düşünüldüğü açlktır. Örneğin, Coğrafyada 1960’lı yılların sonu ve 1970’li yılların başında daha görünür olan Zaman Coğrafyası (Time Geography) mekanistik olması ve sosyal yaklaşımının zayıflığı nedeniyle gözden düşmüştür (Gren, 2009). Yaklaşım, güçlü bir geleneğe/paradigmaya dönüşemediği gibi görünürlüğü de sinırlı kalmıştır.

\section{Sonuç}

Antropoloji, sosyoloji, kültürel çalışmalar, ekonomi ve tarih gibi sosyal disiplinlerin çalışmalarına kısaca göz gezdirdiğimizde; bu disiplinler ile coğrafya arasındaki etkileşimin ve karşılıklı trafiğin ne derece yoğun olduğunu görebiliriz. Bilim dünyası yıllardır süregelen kapsamlı branşlamayı günümüzde disiplinler arası yaklaşımlarla dengelemeye çalışmaktadır (Klein ve Frodeman, 2017). Çünkü olay ve olguları daha iyi anlamak için hem disipliner temelli spesifik bakış açısına hem de disiplinler arası geniş bir perspektife ihtiyacımız bulunmaktadır.

Türkiye'deki coğrafya yapma pratiğindeki metodolojik milliyetçilik aşılması gereken bir sorundur. Çalışma boyunca bu anlayışın sunduğu fikirlerin oldukça yerel olduğunu ve yorumlama kapasitemizi sınırlandırdığını vurgulamaya çalıştık. Lokal metodolojik milliyetçiliğe karşıt olarak coğrafi perspektifin daha geniş olduğu metodolojik kozmopolitanizm çözüme katkı sunacak bir seçenek olarak görülmelidir.

Tarih yazımında oluşturduğumuz ve kullandığımız çerçeve ve formlar önemli oranda disiplinin tarihini etkilemektedir. Benimsediğimiz çerçeveler, etkilendiğimiz teoriler ve bakış açılarımız disiplinin tarihinin her noktasına etkilerini bırakmaktadır. Bu nedenle, coğrafyanın tarihini yazarken sadece geçmişten yararlanıyoruz yaklaşımı gerçeği yansıtmamaktadır. Geçmiş kadar olmasa bile, tarih yazımı coğrafi disiplinde anlamları ve tanımları oluşturmada etkili olmuştur/olacaktır.

Coğrafyanın ne olduğu kadar ne olmadığı da önemli dönüşümler geçirmiştir. Her ne kadar halk arasında Coğrafya başkent, şehir, nehir ve dağ ismi ezberlemek şeklindeki coğrafya tanımı hala canlı olsa da bunun Coğrafya olmadığının daha anlaşılır bir şekilde aktarılması gerekmektedir. Sadece akademi içindeki değişim yeterli değildir. Coğrafyanın ne anlama 
geldiğini geniş kitlelere daha doğru bir şekilde aktarma görevi de elbette coğrafyacılara düşmektedir.

Bir kişinin kendisini, çalıştığı disiplini veya herhangi bir şeyi tanımlaması zordur. Tanımlamanın bizzat kendisi zordur ve bazı sakıncaları da beraberinde getirir. Birincisi, tanımlama belirli bir netliği sağladığı gibi, birçok özelliğin dişarda kalmasına yol açar. İkincisi, değişim süreklilik arz eden bir gerçeklik olmasına karşın tanımlamalar ister istemez sabitliği ve durağanlığı beraberinde getirir. Değişmezlik vardır algısına yol açar. Bu nedenle tanımlama yapacak olsak bile (çoğu zaman yapmak zorundayız) bu tanımlamaların sıklıkla gözden geçirilmesi gerekir. Üçüncüsü, yapılan tanımlamalar bizzat gerçeği yansıtmakta mıdır? Tanım ve tanımı yapılan gerçeklik arasındaki ilişki ne düzeydedir? Bu nokta önemlidir, zira yapılan tanımlamalar yanlış bile olsa uzun zaman hafızalardan kolayca silinmez. Tanım ve tanımı yapılan gerçekliğin yüzde yüz uyuşmayacağının farkında da olsak en azından birbirilerine yakın durmalarına özen gösterilmelidir.

Michel Foucault (1972), "bana kim olduğumu sormayın ve ayn kalmamı istemeyin" derken, Slovaj Zizek (2016) ise, bir söyleşide kendisine yöneltilen "siz kimsiniz?" şeklindeki bir soruyu "kim olduğumu bilmiyorum, bilmek de istemiyorum" demektedir. Bu iki etkili teorisyenin sözlerinden tanımlamalara şüpheyle yaklaştıkları; değişmez tanımlamalara inanmadıkları ve değişimin sürekliliğine olan vurgularını çıkarabiliriz. Teorisyenlerin çıkarımları doğru da olsa hayatın her alanında tanım yapıyoruz ve yapmaya zorlanıyoruz. Anlamı oluşturmada ve iletmede en önemli araç dil olduğu için tanım yapmaktan vazgeçemiyoruz. Tanımları eleştirebilir, revize edebilir veya tamamen değiştirebiliriz; fakat onlarsız yapamayız

Coğrafyada yapılan tanımların birçoğu günümüzde yetersiz veya geçersiz bulunmaktadır. Örneğin, coğrafya yerin tasviridir tanımı günümüzde coğrafyacıların büyük çoğunluğu tarafından kabul edilmez. Coğrafya, yeryüzü üzerindeki farklı bölgelerin ortaya çıkarılması ve bu bölgelerin tasvirinin yapılmasıdır şeklindeki tanım da çoğu coğrafyacı tarafından kabul edilmez ve gözden düşmüştür (Johnston ve Sidaway, 2015; Nayak ve Jeffrey, 2011). Coğrafya, insan ve çevre arasındaki etkileşimleri inceler şeklindeki tanım ilk iki tanım kadar olmasa bile günümüzde sorunlu görülmektedir. Zira bu tanımda, insan ve çevrenin ayrı varlıklar gibi düşünülmesi; iç içe değil de sadece etkileşime giren iki ayrı unsurlar olarak görülmesi problemlidir. Coğrafya, insan ve mekân arasındaki karşılıklı etkileşimleri mekânsal perspektiften ele alır (Coe, Kelly ve Yeung, 2019) şeklindeki tanım ise günümüzde yaygın bir şekilde kabul edilmektedir. 
Tanım ve disiplinin kendisi ayrı şeyler değildir ve ikisi de sürekli değişmektedir. Değişim elbette her zaman disiplinin tümünü kapsamayabilir. Bazen bir yaklaşım, teori veya metot gözden düşerken bazen büyük paradigma değişiklikleri yaşanabilir. Örneğin, 1960’lı yılların sonunda coğrafya diğer sosyal bilim dallarında olduğu gibi büyük bir değişim ve dönüşüm yaşamıştır. Bu değişiklik sırasında coğrafya literatüründeki birçok temel kavramın içeriği ve tanımı sorgulanmıştır (Cresswell, 2012). Bu nedenlerle tanımların geçiciliğini, sabit olmadıklarını ve yeni anlayışlarla zamanla gözden düşeceklerinin bilinciyle şöyle bir coğrafya tanımı yapabiliriz:

Coğrafya, insan ve mekânı iç içe gören; tüm olay, olgu ve faaliyetleri mekânsal perspektiften okuyan; insan-mekân etkileşiminin ortaya çıkardığ sonuçların neler olduğunu anlamaya, yorumlamaya ve açıklamaya çalışan sosyal bir disiplindir.

\section{Kaynakça}

Acemoglu, D. \& Robinson, J. (2012). Why Nations Fail: the Origins of Power, Prosperity, and Poverty. Random House Digital, Inc.

Agnew, J. (2002). Geopolitics. London: Routledge (second edition).

Agnew, J. (2003). Making Political Geography. London: Arnold.

Agnew, J. (2011). Space and place. In J. A. Agnew \& D. Livingstone (Eds.), Sage Handbook of Geographical Knowledge. London: SAGE.

Ankersmit, F. R., Domańska, E. \& Kellner, H. (eds.) (2009). Re-figuring Hayden White. Stanford, CA: Stanford University Press.

Anlı, Ö. F. (2016). Pozitivist ve Konvansiyonalist Bilim Anlayışları Bağlamında Coğrafya Disiplininin Konumu. Düşünme Dergisi/Journal of Thinking, 9, 37-59.

Anlı, Ö. F. (2017). Bilim, Sosyal Bilim ve Coğrafya: Bilgi-kuramsal Bir Yeniden Ziyaret. Kilikya Felsefe Dergisi, 4(3), 34-73.

Arı, Y. (2017). Çevresel Determinizmden Politik Ekolojiye: Son 100 Yılda Dünya'da ve Türkiye'de Insan-Çevre Coğrafyasındaki Yaklaşımlar. Doğu Coğrafya Dergisi, 22(37), 1-34.

Arı, Y. (2019). Yenilik ve Bilimsel gelişme: Türk Coğrafya Tartışma Listesinin (Coğrafya) Içerik Analizi (1997-2012). International Journal of Geography and Geography Education, 39, 95-120.

Bachmann-Medick, D. (2007). Cultural Turns: Neuorientierungen in den Kulturwissenschaften (2nd ed.). Reinbek: Rowohlt.

Bathelt, H. \& Glückler, J. (2011). The Relational Economy: Geographies of Knowing and Learning. Oxford: Oxford University Press.

Bekaroğlu, E. \& Yavan, N. (2018). Türk coğrafyacılığında dört gelenek: Ampirik bir analiz. Marmara Coğrafya Dergisi, 37, 79-93.

Beck, U. (2009). World at Risk. Cambridge: Polity Press.

Bilgili, M. (2020). Coğrafyada Mekân Felsefesi Üzerine Yaklaşımlar. International Journal of Geography and Geography Education , (41) , 88-102. 
Bondi, M. (2014)."Changing voices: Authorial voice in abstracts." In Abstracts in Discourse: Variation and Change. by M. Bondi, \& R. Lor_es Sanz (Eds.), Bern: Peter Lang.

Coe N. M., Kelly, P. F. \& Yeung, H. (2019). Economic Geography. 5th Edition. Wiley Blackwell.

Crang P. (1997). Cultural Turns and The (Re)constitution of Economic Geography: Introduction to Section One in Lee R and Wills J (eds), Geographies of Economies London: Arnold, 3-16.

Cresswell, T. (2012). Geographic Thought: A Critical Introduction. Hoboken: Wiley.

Deniz, A. (2020). Who Cares Whom? Gendered Care Circuits And Transnational Migration of Ukrainians in Turkey, DTCF Dergisi 60.1 (2020): 312-334.

Dodds, K., Kuus, M., \& Sharp, J. (eds) (2013). The Ashgate Research Companion to Critical Geopolitics. Farnham: Ashgate.

Fairclough, N. (2013) Language and Power. 2nd ed. Routledge.

Foucault, M. ( 1972) The Archaeology of Knowledge, New York: Pantheon

Frodeman, R. (2017). The Future of Interdisciplinarity: An Introduction to the 2nd Edition. In: The Oxford Handbook of Interdisciplinarity, Second Edition. Edited by Robert Frodeman, Julie Thompson Klein, and Roberto C. S. Pacheco: Oxford University Press.

Gren, M. (2009): 'Time geography', in Kitchin, R. And Thrift, N. (eds): International Encyclopedia of Human Geography. Elsevier, Oxford, pp. 279-284.

Gregory, D. (2009). Geography. In Johnston, R. J., Gregory, D., Pratt, G. Watts, M, Whatmore, S. (eds.) The Dictionary of Human Geography (5th ed.), Wiley-Blackwell.

Harvey, D. (2012). Rebel Cities: From the Right to the City to the Urban Revolution. London: Verso.

Hobsbawm, E. (1983). Introduction: Inventing traditions. In E. Hobsbawm \& T. Ranger (Eds.), The Invention of Tradition (pp. 1-14). Cambridge, UK: Cambridge University Press.

Hubbard, P., Kitchin, R., Bartley, B. \& Fuller, D. (2002). Thinking Geographically: Space, Theory and Contemporary Human Geography. London: Continuum.

Jenkins, K. (1991). Re-thinking History, London and New York: Routledge

Jessop B. \&Sum N. L. (2003). On Pre- and Post-Disciplinarity in (Cultural) Political Economy, Économie et société-Cahiers de l'ISMEA, 39(6), 993-1015.

Johnston, R. \& Sidaway, J. D. (2015). Geography and Geographers: Anglo-American Human Geography Since 1945. Broken Sound Pkwy: Taylor and Francis.

Klein, J. T. (2017). Typologies of Interdisciplinarity: The Boundary Work of Definition. In: The Oxford Handbook of Interdisciplinarity, Second Edition. Edited by Robert Frodeman, Julie Thompson Klein, and Roberto C. S. Pacheco: Oxford University Press.

Klein, J. T. \& Frodeman, R. (2017). Interdisciplining Humanities: A Historical Overview. In: The Oxford Handbook of Interdisciplinarity, Second Edition. Edited by Robert Frodeman, Julie Thompson Klein, and Roberto C. S. Pacheco: Oxford University Press.

Kurtar, S. (2020). Mekân Varyasyonları, Senem Kurtar (editör), NotaBene Yayınları.

Lacoste, Y. (1976). Coğrafya Savaşmak içindir. (Çev. A. Arayıcı) (1998) Özne Yayınları. İstanbul

Livingstone, D. (2009). History of Geography. In Johnston, R. J., Gregory, D., Pratt, G. Watts, M, Whatmore, S. (eds.) The Dictionary of Human Geography (5th ed.), Wiley-Blackwell.

Livingstone, D. (1992). The Geographical Tradition: Episodes in the History of a Contested Enterprise. Oxford, UK: Blackwell.

Mesle, C. R. (2008). Process-relational Philosophy: An introduction to Alfred North Whitehead. West Conshohocken, PA: Templeton Foundation Press. 
Mirioğlu, G. (2018). Kentlere Feminist Coğrafya Perspektifinden Bakmak. Ege Coğrafya Dergisi, 27 (2), 183-194

Moran, J. (2002). Interdisciplinarity. London, UK, and New York: Routledge.

Munslow, A. (1997). Deconstructing History, London: Routledge.

Munslow, A. (2000) The Routledge Companion to Historical Studies, London, Routledge

Nardo, D. (2002). Greek and Roman Mythology, New York: Greenhaven Press.

Nayak, A. \& Jeffrey, A. (2011). Geographical Thought. Taylor and Francis.

Nelson, L. \& Seager, J. (Eds.). 2005. Companion to Feminist Geography. Blackwell, London.

Öksüz, M. \& Deniz, A. (2019). Toplumsal Cinsiyetin, Mekânın ve Zamanın Tektipleştirilmesi: Tecavüz İçerikli Karikatürler ve Gerçek Temsiller Üzerine Bir Araştırma, Coğrafi Bilimler Dergisi/ Turkish Journal of Geographical Sciences, 17(1), 170-192.

Özgür, E. M. (2018). Türk Beşeri Coğrafyasında Yenileşme Eğilimleri: Değişim Aktörlerinin Perspektifinden Bir Değerlendirme. International Journal of Geography and Geography Education (IGGE), 38, 142-170.

Özgür, E., M. (2019). Yaşlanmanın Coğrafyaları: Coğrafi Gerontolojide İlerleme, Tartışmalar ve Araştırma Gündemi (The Geographies of Ageing: Progress, Debates and Research Agenda in Geographical Gerontology) Coğrafi Bilimler Dergisi, 17(1), 78-109.

Özkaya, A. (2020). Post-Coğrafya, Kırmızı Çatı Yayınları, Ankara.

Packer, M. (2011). The Science of Qualitative Research. Cambridge University Press.

Peet R. (1998). Modern Geographical Thought (Blackwell, Oxford).

Sayer, A. (1992) Method in Social Science. London: Routledge.

Sayer, A. (2000) Realism and Social Science. London: Sage.

Sharp, J. (2008). Critical Geopolitics (1996). Gearóid Ó Tuathail. In Hubbard, P., Kitchin, R., \& Valentine, G. (eds), Key Texts in Human Geography, Thousand Oaks, CA: Sage, 189-196.

Springer, S. (2018). Anarşizm ve Coğrafya: Anarşist Coğrafyanın Kısa Bir Şeceresi, Çeviren: Mehmet Ali Toprak, Posseible Düşünme Dergisi, Sayl: 12.

Srf Kültür (2016). https://www.srf.ch/play/tv/sternstunde-philosophie/video/slavoj-zizek-nieder-mit-der-ideologie?id=3f5e 5a47-36d7-43c0-ae5f-28deeaae256b adresinden $7 \mathrm{Ma}$ yıs 2020 tarihinde erişilmiştir.

Tuathail, G. (1996). Critical Geopolitics. London: Routledge

Tuathail, G., \& Dalby, S. (1998). Rethinking Geopolitics: Towards a Critical Geopolitics. In Ó Tuathail, G., \& Dalby, S. (eds), Rethinking Geopolitics, London: Routledge, $1 \otimes 15$.

Tuncer, S. (2018). Women and Public Space in Turkey: Gender, Modernity and the Urban Experience. New York: I.B. Tauris.

Tüysüz, S. \& Gülmez, R. (2019). Instrumentalisation of gerrymandering in recentralization in Turkey: The case of Ankara. International Journal of Geography and Geography Education (IGGE), 40, 139-150.

Uysal, A. (2015). Çocuk Coğrafyaları ve Çocukların Gündelik Mekânları (Children Geographies and Everyday Spaces of Children), idealkent, Sayı 17, ss. 46-61.

White, H. (1987). The Content of the Form: Narrative Discourse and Historical Representation, Baltimore, MD: Johns Hopkins University Press.

Yakar, M. \& Südaş, i. (2019). Türkiye'de Yabancı Nüfusun Yeni Coğrafyaları. Ege Coğrafya Dergisi, 28(2), 129-164. 